\title{
Research in health
}

promotion and

nursing

Edited by

Jenifer Wilson-Barnett

and

Jill Macleod Clark 
Selection, editorial matter, Introduction (C) Jenifer Wilson-Barnett and Jill Macleod Clark 1993

Individual chapters (in order) (C) Keith Tones, Jenifer Wilson-Barnett, Alastair V. Campbell, Alan Cribb, Janet M. Walker, Alison Dines, Ursula Gallagher and Jerry Burden, Jenifer Wilson-Barnett and Sue Latter, Sue Latter, Karen Jones, Julienne Meyer, Mary Flatley, Sally Kendall, Martin Bradford and Sandra Winn, Ann C. Pursey and Karen A. Luker, Judith B. Igoe, Marjaana Pelkonen, Mary J. Renfrew, Charles Brooker, Katharine Ferguson, Joan Foulkes, Marie Johnston and Catherine Robertson, Kathleen Rowe and Jill Macleod Clark, Mary Malone and Liz Mirrabeau, Deborah McCaffrey Boyle, Jane Goodeve, Sarah E. Adams, June Lunney, Jill Macleod Clark, 1993

All rights reserved. No reproduction, copy or transmission of this publication may be made without written permission.

No paragraph of this publication may be reproduced, copied or transmitted save with written permission or in accordance with the provisions of the Copyright, Designs and Patents Act 1988, or under the terms of any licence permitting limited copying issued by the Copyright Licensing Agency, 90 Tottenham Court Road, London WIP 9HE.

Any person who does any unauthorised act in relation to this publication may be liable to criminal prosecution and civil claims for damages.

First published 1993 by

THE MACMILLAN PRESS LTD

Houndmills, Basingstoke, Hampshire RG21 2XS

and London

Companies and representatives

throughout the world

ISBN 978-0-333-60134-1 ISBN 978-1-349-23067-9 (eBook)

DOI 10.1007/978-1-349-23067-9

A catalogue record for this book is available from the British Library.

Typeset by Cambrian Typesetters, Frimley, Surrey

Whilst every effort has been made to ensure the accuracy of the contents of this publication, the publishers and authors expressly disclaim responsibility in law for negligence or any other cause of action whatsoever. 
The contributors

Introduction

Jenifer Wilson-Barnett and Jill Macleod Clark

1 The theory of health promotion: implications for nursing Keith Tones

\section{Section One: Theoretical issues}

2 The meaning of health promotion: a personal view Jenifer Wilson-Barnett

3 The ethics of health education Alastair V. Campbell

4 Health promotion - a human science Alan Cribb

5 A social behavioural approach to understanding and promoting condom use Janet $M$. Walker

6 A case study of ethical issues in health promotion - mammography screening: the nurse's position Alison Dines

7 Nursing as health promotion - a myth accepted? Ursula Gallagher and Jerry Burden

\section{Section Two: Health promotion in practice}

8 Factors influencing nurses' health education and health promotion practice in acute ward areas Jenifer Wilson-Barnett and Sue Latter

9 Health education and health promotion in acute ward settings: nurses' perception and practices Sue Latter

10 Opportunities for health education: an analysis of nurse-client interactions in acute areas 
11 Lay participation in care: threat to the status quo Julienne Meyer

12 Hospitalization and discharge of stroke patients:

the relatives' experiences

Mary Flatley

13 Client participation in health promotion encounters with health visitors

Sally Kendall

14 Practice nursing and health promotion: a case study Martin Bradford and Sandra Winn

15 Assessment of older people at home - a missed opportunity?

Ann C. Pursey and Karen A. Luker

Section Three: Developing the nurse's health promotion role

16 Healthier children through empowerment Judith B. Igoe

17 Description of Facilitative Nursing interventions in primary health care: preliminary results

Marjaana Pelkonen

18 Towards healthier families Mary J. Renfrew

19 Evaluating the impact of training community psychiatric nurses to educate relatives about schizophrenia: implications for health promotion at the secondary level Charles Brooker

20 Meeting mental health education needs of patients

- the potential role of the psychiatric nurse

Katharine Ferguson

\section{Section Four: The nurse's role in promoting healthy lifestyles}

21 Knowledge and distress: implications for cardiac recovery programmes Joan Foulkes, Marie Johnston and Catherine Robertson

22 Evaluating the effectiveness of the coronary care nurses' role in smoking cessation Kathleen Rowe and Jill Macleod Clark

23 Working with a women's slimming group: a case study of health promotion Mary Malone and Liz Mirrabeau

24 Healthy living after illness

Deborah McCaffrey Boyle 
25 Teaching aids: a study of school nurses' views of their role in HIV/AIDS education Jane Goodeve

26 Occupational health policies for the health service Sarah E. Adams

\section{Section Five: Future directions}

27 Development of a programme of health promotion research

28 From sick nursing to health nursing: evolution or revolution?

Jill Macleod Clark

Index 


\section{The contributors}

Ms S.E. Adams

Service Manager

Bloomsbury and Islington Health

Authority

Highgate Hill

London

Ms D. McCaffrey Boyle

Oncology Nurse Lecturer and

Consultant

Washington, DC

USA

Mr M. Bradford

Research Assistant

Health and Social Policy Research Centre

Department of Community Studies

Brighton University of East Sussex

Lewes Road

Brighton

East Sussex

Mr C. Brooker

Regional Nurse, Research

Trent Regional Health Authority

Fulwood House

Old Fulwood Road

Sheffield

Mr J. Burden

Charing Cross Hospital

Fulham Palace Road

London

Professor A. Campbell

Professor of Biomedical Ethics

Biothics Research Centre

Otago Medical School

Dunedin

New Zealand

Dr A. Cribb

Lecturer in Education

Centre for Educational Studies

London

Ms A. Dines

Lecturer in Nursing Studies

King's College London

Strand

London
Ms K. Ferguson

Lecturer

Department of Nursing

Manchester University

Manchester

Ms M. Flatley

Research Student

Department of Nursing Studies

King's College London

Strand

London

Ms. J. Foulkes

Psychology Department

University of St Andrew's

Fife

Scotland

Ms U. Gallagher

Charing Cross Hospital

Fulham Palace Road

London

Ms J. Goodeve

Research Student

Department of Nursing Studies

King's College London

Strand

London

Professor J. Igoe

Associate Professor/Director

School Health Programmes

University of Colorado

Health Sciences Centre

Colorado

USA

Professor M. Johnston

Psychology Department

University of St Andrew's

Fife

Scotland

Ms K. Jones

Research Associate

Department of Nursing Studies

King's College London

Strand

London 
Ms S. Kendall

Reader

Faculty of Health Studies

Buckinghamshire College

Queen Alexandra Road

High Wycombe

Bucks

\section{Ms S. Latter}

Lecturer

Department of Nursing Studies

Normanby College

King's College Hospital

London

Professor K. Luker

Department of Nursing

Liverpool University

Rodney House

70 Mount Pleasant

Liverpool

\section{Mr J. Lunney}

Nurse Science Administrator

Health Promotion/Disease

Prevention Branch

National Center for Nursing Research

Bethesda, MD

USA

Professor J. Macleod Clark

Department of Nursing Studies

King's College London

Strand

London

Ms M. Malone

Health Visitor

Lewisham and North Southwark

Health Authority

Ms Julienne Meyer

Lecturer

Department of Nursing Studies

King's College London

Strand

London

Dr L. Mirrabeau

Head of School of Advanced Nursing

North East Surrey College of Technology

Nescot

Reigate Road

Ewell

Surrey
Ms Marjaana Pelkonen

Senior Lecturer

Department of Nursing

University of Kuopio

Finland

Ms A. Pursey

Department of Nursing

Liverpool University

PO Box 147

Liverpool

Ms M. Renfrew

Midwife Researcher/Director

National Perinatal Epidemiology Unit

Oxford

Ms C. Robertson

Psychology Department

University of St Andrew's

Fife

Scotland

Ms K. Rowe

Department of Nursing Studies

King's College London

Strand

London

Professor K. Tones

Health Education Unit

Leeds Metropolitan University

Leeds

Ms J. Walker

Clinical Psychologist

Reader in Nursing Studies

Department of Nursing, Health and

Community Studies

Bournemouth University

Dorset

Professor J. Wilson-Barnett

Department of Nursing Studies

King's College London

Strand

London

Ms S. Winn

Lecturer in Social Policy

Health and Social Policy Research Centre

Department of Community Studies

Brighton University of East Sussex

Lewes Road

Brighton 